Received $\quad 01.10 .2015$

Reviewed 19.02 .2016

Accepted 25.02.2016

A - study design

B - data collection

C - statistical analysis

D - data interpretation

$\mathbf{E}$ - manuscript preparation

F - literature search

\title{
The importance of calibration parameters on the accuracy of the floods description in the Snyder's model
}

\author{
Andrzej WALEGGA
}

University of Agriculture in Cracow, Department of Sanitary Engineering and Water Management, Mickiewicza Ave 24/28, 30-059 Kraków, Poland; e-mail: a.walega@ur.krakow.pl

For citation: Wałęga A. 2016. The importance of calibration parameters on the accuracy of the floods description in the Snyder's model. Journal of Water and Land Development. No. 28 p. 19-25.

\begin{abstract}
Comparison of quality of Snyder's model for determination flood waves was examination in this work. Model parameters were calibrated based on objective functions: percentage error in peak flow ( $P E P F)$, percentage error in volume $(P E V)$, peak-weighted root mean square error ( $P W R M S E)$, sum of absolute residuals $(S A R)$ and sum of squared residuals $(S S R)$. Quality of model was calculating by Nash-Sutcliffe efficiency coefficient $E$. Additionally sensitivity of a model was characterized by its flexibility. The analyses were performed in the watershed of Grabinka. It has been found that the use PWRMSE as the objective function allows to obtain the best quality results of simulation. Furthermore, Snyder's model is flexible to the change of $C_{p}$ coefficient.
\end{abstract}

Key words: efficiency of model, flexibility of model, objective function, unit hydrograph

\section{INTRODUCTION}

Estimating an appropriate design value for extreme flood events such as maximum water levels, discharges, or runoff is one of the most important tasks of the design process for a large number of engineering projects and studies that reduce the impact of flooding [GĄDEK 2014; KARABOVÁ et al. 2012; VAŠŠOVA 2013]. Unfortunately, in many streams are ungauged and do not have flow records. Even when stream gauges are in place, the record is often too short to accurately predict extreme events [KHALEGHI et al. 2014]. In this case, for the estimation of design floods and volumes, often, event-based hydrological models are applied. Simulation models of watershed hydrology are extensively used for water resources planning and management. These models can offer a sound scientific framework for watershed analyses of water movement and provide reliable information on the behavior of the system [JHA 2011]. In practice hydrologists uses a synthetic unit hydrograph to transformation of effective rainfall to runoff. A synthetic unit hydrograph is a unit hydrograph derived following an established formula, without the need the rainfall-runoff data analysis [WAŁĘGA 2013; WAŁĘGA et al. 2011]. This includes Snyder's method, Soil Conservation Service (SCS) method, Gray's method and Clark's instantaneous unit hydrograph method. Understanding the hydrology of a watershed and modeling different hydrological processes within a watershed are therefore very important for assessing the environmental and economical well-being of the watershed. Besides successful application of hydrological models, there are several issues that question the model output such as uncertainty in input parameters, nonlinear relationships between hydrologic input features and hydrologic response, and the required calibration of numerous model parameters. These issues can be examined with sensitivity analyses of the model parameters to identify sensitive parameters with respect to their impact on model outputs. Proper attention to the sensitive parameters may lead to a better understanding and to better estimated values and thus to reduced uncertainty [LENHART et al. 2002]. The 
parameters of a model are estimated in the calibration process, which involves minimization of variation between the observed and calculated values. The previous ,manual" calibration technique, which involved adjusting model parameters and verifying the simulation results, has been replaced with algorithms allowing for automation of the process, e.g. Monte Carlo method [BAHREMAND, DE SMEDT 2008]. Selection of automatic calibration algorithm depends on the criterion adopted for qualitative assessment of the model. Important part of calibration processes is sensitivity analysis. The sensitivity analysis allows examining the interactions between model parameters and obtained simulation results. This analysis enables, among others, to determine the contribution of individual parameters or combinations thereof in the final outcome of the simulation. Automatic calibration process is frequently supplemented by a selection of algorithm to optimize the parameters. This is a very important phase of calculations as, if properly completed, it allows obtaining optimal parameter values and thus achieving the best adjustment of the model to the actual course of the analyzed phenomenon.

The aim of this study was to evaluate the impact of the calibration process, using a variety of measures, on the accuracy of the phenomenon's description by the Snyder's synthetic unit hydrographs.

\section{MATERIAL AND METHODS}

The analyses were performed in the watershed of Grabinka - the left secondary tributary of the Wisłoka River - Figure 1, located in the southern part of Poland. The area of the watershed is $218.68 \mathrm{~km}^{2}$, the average drop equals $5.46 \%$, and the length of the main watercourse is $32.82 \mathrm{~km}$. In the analyzed watershed quaternary deposits lay on the Miocene clays: sands with boulders, boulder clays and fluvial sands. The watershed is dominated by well and average permeable soils and the land cover is mostly represented by agricultural land and forests.

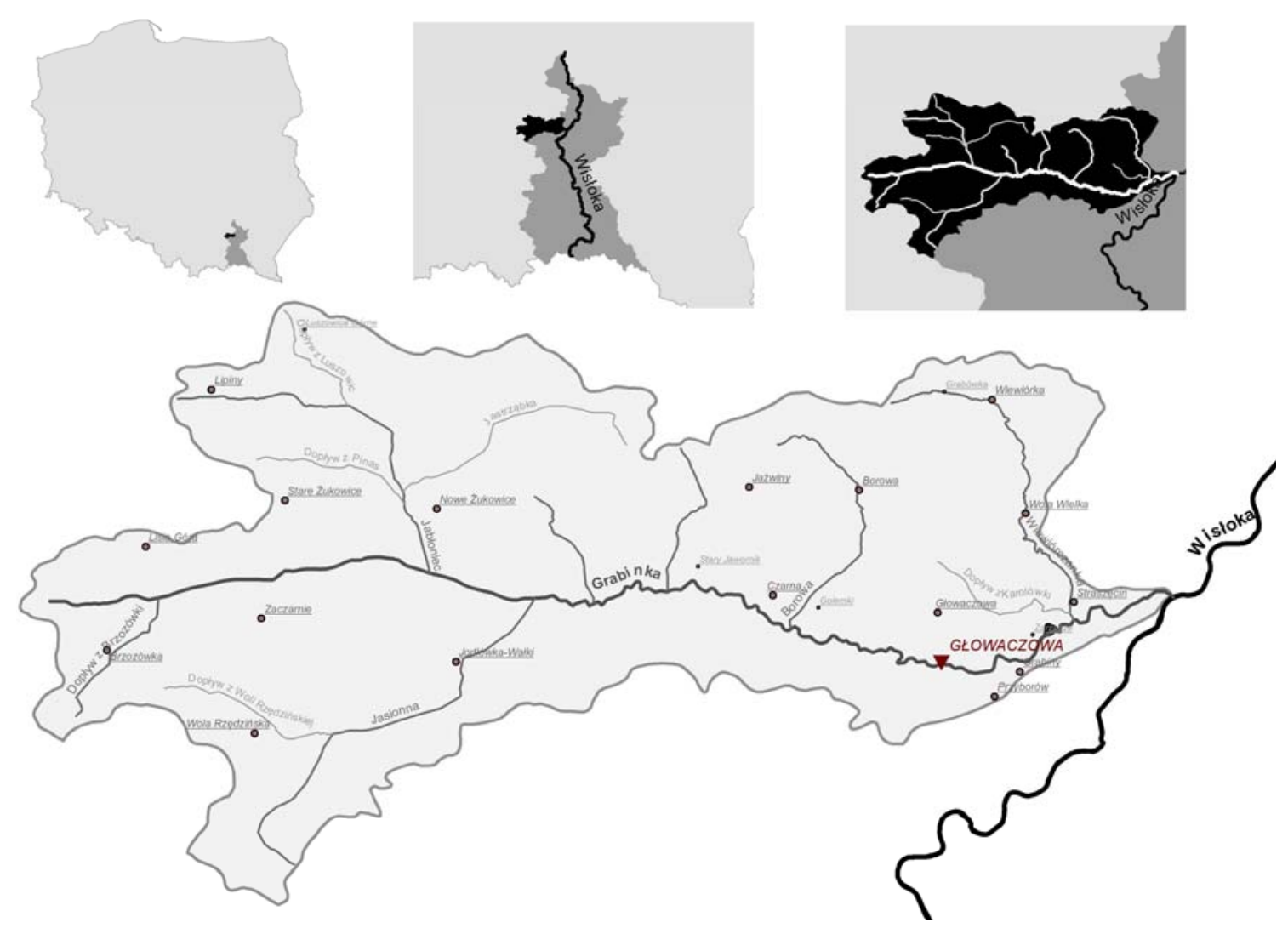

Fig. 1. Watershed of Grabinka; source: WAŁĘGA [2014] modified

The analysis was based on the highest daily precipitation recorded at the Tarnów precipitation station and the corresponding flood hydrographs observed in the cross-section of Głowaczów water gauge, which closes the Grabinka watershed. The analysis was based on the episodes of 1980, 1981, 2004 and 2006. These data originated from the archives of Institute of Meteorology and Water Management, National Research Institute.
Due to the availability of only point precipitation data, before the analysis they were transformed into precipitation distributed on the watershed area based on the precipitation reduction curves as functions of duration and watershed area, presented by PONCE [1989]. Effective precipitation, which describes direct discharge, was determined by SCS method [SOCZYŃSKA 1997]. In the presented study the value of $C N$ parameter was determined by optimization using 
the observed rainfall-discharge phenomenon. The Snyder's model based on synthetic unit hydrographs was subjected to the calibration process.

In 1938 Snyder introduced the concept of a synthetic unit hydrograph. Based on the analysis of a large number of hydrographs for watersheds in the Appalachian region the author derived the following equation for the lag time:

$$
T_{\text {lag }}=0.75 C_{t}\left(L L_{c}\right)^{0.3}
$$

where: $T_{\text {lag }}=$ lag time, hours; $C_{t}=$ coefficient dependent on the watershed slope and related to watershed retention; $L=$ distance along the main stream, from the estuary section to crossing of dry valley with water divide, $\mathrm{km} ; L_{c}=$ distance along the main stream from the estuary section to the watershed gravity center, $\mathrm{km}$.

The flow in the culmination is calculated from the following equation:

$$
Q_{p}=\frac{0.275 C_{p} \cdot A}{T_{\text {lag }}}
$$

where: $Q_{p}=$ flow in the culmination of unit hydrograph caused by effective precipitation of $1 \mathrm{~cm}$ height, $\mathrm{m}^{3} \cdot \mathrm{s}^{-1} ; A=$ watershed area, $\mathrm{km}^{2} ; C_{p}=$ empirical coefficient resulting from simplifying the shape of the hydrograph into the triangle [PONCE 1989].

Time to peak is calculated from the equation:

$$
T_{p}=\frac{D}{2}+T_{\text {lag }}
$$

where: $T_{p}=$ time to peak, hours; $T_{\text {lag }}=$ lag time, hours; $D=$ duration of effective precipitation, hours.

In the first stage of the calculations, model parameters were automatically calibrated based on the following measures (objective functions): percentage error in peak flow $(P E P F)$, percentage error in volume $(P E V)$, peak-weighted root mean square error (PWRMSE), sum of absolute residuals (SAR) and sum of squared residuals $(S S R)$. All characteristics are specified with the equations [CUNDERLIK, SIMONOVIC 2004]:

$$
\begin{gathered}
P E P F=100\left[\frac{Q_{o}-Q_{s}}{Q_{o}}\right] \\
P E V=100\left[\frac{V_{o}-V_{s}}{V_{o}}\right] \\
P W R M S E=\sqrt{\frac{\sum_{t=1}^{N}\left(Q_{o t}-Q_{s t}\right) \frac{Q_{o t}+Q_{\text {ave }}}{2 Q_{v v e}}}{N}} \\
Q_{\text {ave }}=\frac{1}{N} \sum_{t=1}^{N} Q_{o t} \\
S A R=\sum_{t=1}^{N}\left|Q_{o t}-Q_{s t}\right|
\end{gathered}
$$

$$
\operatorname{SSR}=\sum_{t=1}^{N}\left[Q_{o t}-Q_{s t}\right]^{2}
$$

where: $Q_{o t}$ and $Q_{s t}=$ observed and simulated flow in time $t ; Q_{\text {ave }}=$ average observed flow; $V_{o}$ and $V_{s}=$ volumes of observed and simulated wave.

Automatic calibration of model parameters was based on iterative selection of the parameters until the minimum of the objective function. In order to minimize the objective function (4) to (8) a uniform gradient method was applied. This involves estimating the value of one parameter while maintaining the remaining stable.

The final evaluation of the calibration process was based on Nash-Sutcliffe efficiency coefficient $E$ [NASH, SUTCLIFFE 1970], commonly used in hydrology:

$$
E=\left[1-\frac{\sum_{i=1}^{i=N}\left(Q_{o i}-Q_{s i}\right)^{2}}{\sum_{i=1}^{i=N}\left(Q_{o i}-\overline{Q_{o}}\right)^{2}}\right]
$$

where: $N=$ number of hydrograph ordinates, $i=$ index changing from 1 to $N, Q_{o i}=i^{\text {th }}$ ordinate of the observed hydrograph, $Q_{s i}=i^{\text {th }}$ ordinate of the simulated hydrograph, $\bar{Q}_{\sigma}=$ average of the observed hydrograph ordinates.

Sensitivity of a model was characterized by its flexibility, which is a measure of impact of one parameter on another. It is a non-unitary parameter, which is calculated as the ratio of the percentage change in the output characteristics to the percentage change in input parameter [MAIDMENT, HOOGERWERF 2002; WAŁĘGA 2014]. If values of this parameter are higher or equal to 1, then the parameter is "flexible", in other words, the dependent variable is very sensitive to the size of independent variable. Otherwise, when flexibility is lower than 1, the parameter is "inflexible" and the dependent variable is not sensitive to the change of independent variable. The aim of the sensitivity analysis was to determine the effect of time lag and the $C_{p}$ coefficient in Snyder's model on the variability of culmination flow in a simulated hydrograph. The analysis consisted on setting different values of parameters and calculating $Q_{\max }$ flow.

\section{RESULTS AND DISCUSSION}

In the first stage of the analysis the general characteristics of selected flood waves was conducted, which is presented in Table 1. Three out of four of the analyzed waves happened in the summer half-year (waves from 1980, 2004 and 2006), while the wave from 2006 occurred in late May and early June. The mentioned wave from 2006 was characterized by the highest culmination, which reached $43.7 \mathrm{~m}^{3} \cdot \mathrm{s}^{-1}$. The wave from the summer half-year of 2004 was characterized by the longest duration $-480 \mathrm{~h}$. The duration of other waves was similar and did not exceed $240 \mathrm{~h}$. The culmination time was from 24 to $72 \mathrm{~h}$ but the longest time occurred in the wave which was characterized by the lowest culmination among the analyzed 
Table 1. Characteristics of the analyzed flood waves

\begin{tabular}{|c|c|c|c|c|c|c|c|c|c|}
\hline $\begin{array}{c}\text { Date of } \\
\text { wave } \\
\text { occur }\end{array}$ & $Q_{\max }$ & $Q_{b}$ & $T_{b}$ & $T_{w}$ & $T_{o}$ & $V_{c}$ & $V_{w}$ & $V_{o}$ & $\alpha$ \\
\hline 08.1980 & 37.50 & 1.49 & 240 & 24 & 216 & 7.85 & 3.37 & 4.46 & 9.00 \\
\hline 03.1981 & 25.00 & 2.92 & 216 & 24 & 192 & 5.45 & 2.41 & 3.04 & 8.00 \\
\hline $\begin{array}{c}07-08 . \\
2004\end{array}$ & 18.00 & 0.61 & 480 & 72 & 408 & 5.86 & 2.04 & 3.82 & 5.70 \\
\hline $\begin{array}{c}05-06 . \\
2006\end{array}$ & 43.70 & 1.85 & 204 & 36 & 156 & 7.71 & 4.06 & 3.65 & 4.30 \\
\hline
\end{tabular}

Explanations: $Q_{\max }=$ flow at culmination, $\mathrm{m}^{3} \cdot \mathrm{s}^{-1} ; Q_{b}=$ flow at wave base, $\mathrm{m}^{3} \cdot \mathrm{s}^{-1} ; T_{b}=$ duration of the wave, $\mathrm{h} ; T_{w}=$ time to culmination, $\mathrm{h} ; T_{o}=$ descending time, $\mathrm{h} ; V_{c}=$ wave volume, $10^{6} \mathrm{~m}^{3} ; V_{w}=$ volume of ascending part of the wave, $10^{6} \mathrm{~m}^{3} ; V_{o}=$ volume of the descending part of the wave, $10^{6} \mathrm{~m}^{3} ; \alpha=$ coefficient of wave slenderness. Source: own study.

waves. The wave with the highest culmination of 43.7 $\mathrm{m}^{3} \cdot \mathrm{s}^{-1}$ was caused by the precipitation of $107.3 \mathrm{~mm}$, while paradoxically the wave of the lowest culmination $-18.0 \mathrm{~m}^{3} \cdot \mathrm{s}^{-1}$ was the result of much higher precipitation $-124.2 \mathrm{~mm}$. This can be explained by the fact that the wave at the turn of May-June 2006 was

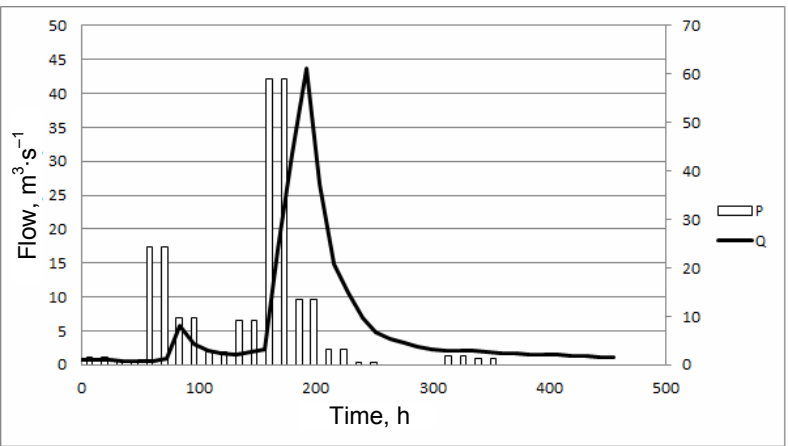

preceded by a long-term precipitation (6-day), which resulted in ground soaking. After this period, precipitation occurred on June $3^{\text {rd }}$ with a height of $59 \mathrm{~mm}$ per day, which caused a distinct culmination - Fig. 2a. Undoubtedly, the culmination of the discussed wave could have been impacted by high groundwater table after a spring snowmelt period. In the case of an episode of July-August 2004, precipitation fell on overdried ground, so despite substantial amount of water, the watershed was characterized by a significant water retention capacity, which greatly reduced the wave culmination - Fig. 2b. The two major waves from 1980 and 2006 were characterized by the largest total volume. Coefficient of slenderness of flood wave $\alpha$, calculated according to CIEPIELOWSKI [1987] as the relation of wave falling time to the culmination time, indicates the fact that the waves from 1980 and 1981 increased very quickly and then the water level slowly descended, whereas the other two waves had slightly smaller imbalance between the descend and increase time.

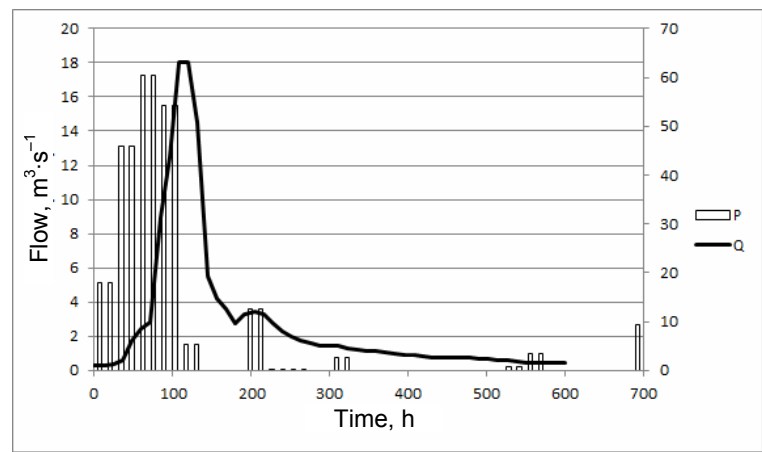

Fig. 2. The course of precipitation and resulting floods in the case of episode a) from 2006 and b) from 2004; source: own study

Table 2 lists the statistical measures of the objective functions for the analyzed waves predicted by Snyder's unit hydrograph.

Table 2. The values of the objective functions described by Snyder's model

\begin{tabular}{|c|c|c|c|c|c|}
\hline \multirow{2}{*}{ Wave } & PEPF & $P E V$ & PWRMSE & \multirow{2}{*}{$\begin{array}{c}S A R \\
\mathrm{~m}^{3} \cdot \mathrm{s}^{-1}\end{array}$} & \multirow{2}{*}{ SSR } \\
\hline & \multicolumn{3}{|c|}{$\%$} & & \\
\hline 1980 & $\begin{array}{c}0.0 \\
(0.0)\end{array}$ & $\begin{array}{c}0.0 \\
(-20.4)\end{array}$ & $\begin{array}{c}3.30 \\
(-6.40)\end{array}$ & $\begin{array}{c}28.9 \\
(-10.8)\end{array}$ & $\begin{array}{c}230.2 \\
(-21.9)\end{array}$ \\
\hline 1981 & $\begin{array}{c}0.0 \\
(0.0)\end{array}$ & $\begin{array}{c}0.0 \\
(-43.0)\end{array}$ & $\begin{array}{c}4.50 \\
(-18.2)\end{array}$ & $\begin{array}{c}50.5 \\
(-25.7)\end{array}$ & $\begin{array}{c}342.3 \\
(-28.6)\end{array}$ \\
\hline 2004 & $\begin{array}{c}0.0 \\
(0.0)\end{array}$ & $\begin{array}{c}78.1 \\
(-10.8)\end{array}$ & $\begin{array}{l}2.80 \\
(6.4)\end{array}$ & $\begin{array}{l}131.6 \\
(63.4)\end{array}$ & $\begin{array}{l}756.6 \\
(18.3)\end{array}$ \\
\hline 2006 & $\begin{array}{c}0.0 \\
(0.0)\end{array}$ & $\begin{array}{c}0.0 \\
(-74.9)\end{array}$ & $\begin{array}{c}5.8 \\
(-19.8)\end{array}$ & $\begin{array}{c}74.9 \\
(-41.5)\end{array}$ & $\begin{array}{c}814.8 \\
(-42.3)\end{array}$ \\
\hline
\end{tabular}

Explanations: $P E P F=$ percentage error in peak flow, $P E V=$ percentage error in volume; $P W R M S E=$ peak-weighted root mean square error, $S A R=$ sum of absolute residuals, $S S R=$ sum of squared residuals, in branches are percentage different between peak flows in observed and simulated wave. Source: own study.

Calculations have shown, that by using the objective function described by formula (4) one can obtain complete consistency between culminations of calcu- lated and observed waves - Table 2. A similar principle shall apply in the case of the other measure $P E V$, except that in this case, the model tends to minimize differences in the volume between the compared waves. Unfortunately, adopting these criteria may have negative impact on the shape of the calculated wave. This is presented in Figure 3, which compares the results of wave simulation from 1980, described by Snyder's model using the PEPF and PWRMSE objective functions.

It should be noted, that the best calibration results were obtained using PWRMSE. Although the differences between flows in culminations and flows observed in PWRMSE are higher than in the one described by the formula (4), the shape of the calculated hydrograph much better describes the entire wave, compared to $P E P F-$ Figure 3. Apart from the $P E P F$ criterion, the best calibration results for each of the analyzed waves were obtained based on PWRMSE Table 2. Flow culminations were slightly underestimated in three out of four analyzed cases. The best calibration results obtained from the PWRMSE model come from the fact that in the optimization procedure the errors of flows located closer to the culmination 

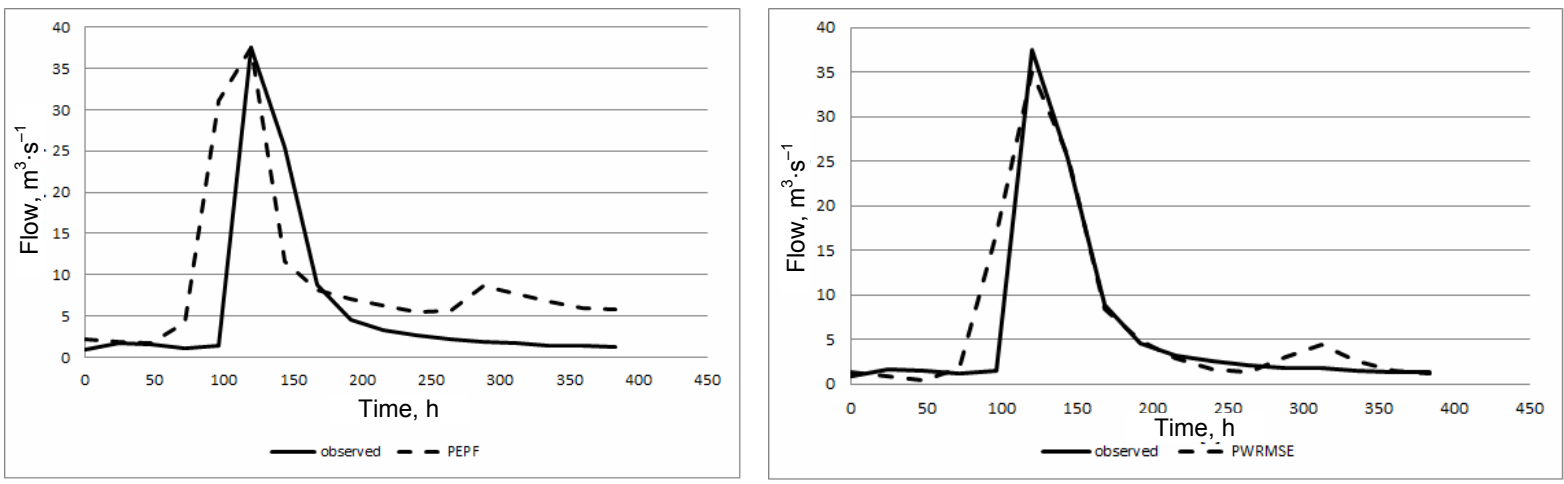

Fig. 3. Comparison of the observed wave from 1980 with the calculated Snyder's model using the objective functions: a) percentage error in peak flow $(P E P F)$ and b) peak-weighted root mean square error (PWRMSE); source: own study

flows are assigned higher weights. In the case of $S A R$ measure, the error weights are independent of their errors, while for $S S R$ measure the weights are higher for high error values and lower for low values. The smallest differences between $Q_{\max }$ were obtained for the wave from 2004 and the highest - for the wave from 2006. Table 3 presented values of parameters of Snyder's model. Parameters of Snyder's model have large variation for analyzed waves and for different objective functions.

Table 3. The values of parameters of the Snyder's model for different objective functions

\begin{tabular}{|c|c|c|c|c|c|c|c|c|c|c|c|c|c|c|c|}
\hline \multirow[b]{2}{*}{ Wave } & \multicolumn{3}{|c|}{$P E P F$} & \multicolumn{3}{|c|}{ PEV } & \multicolumn{3}{|c|}{ PWRMSE } & \multicolumn{3}{|c|}{ SAR } & \multicolumn{3}{|c|}{$S S R$} \\
\hline & $C_{p}$ & $\begin{array}{c}T_{\text {lag }} \\
\mathrm{h}\end{array}$ & $\begin{array}{l}T_{p} \\
\mathrm{~h}\end{array}$ & $C_{p}$ & $\begin{array}{c}T_{\text {lag }} \\
\mathrm{h}\end{array}$ & $\begin{array}{l}T_{p} \\
\mathrm{~h}\end{array}$ & $C_{p}$ & $\begin{array}{c}T_{\text {lag }} \\
\mathrm{h}\end{array}$ & $\begin{array}{c}T_{p} \\
\mathrm{~h}\end{array}$ & $C p$ & $\begin{array}{c}T_{\text {lag }} \\
\mathrm{h}\end{array}$ & $\begin{array}{l}T_{p} \\
\mathrm{~h}\end{array}$ & $C_{p}$ & $\begin{array}{c}T_{\text {lag }} \\
\mathrm{h}\end{array}$ & $\begin{array}{l}T_{p} \\
\mathrm{~h}\end{array}$ \\
\hline 1980 & 0.51 & 19.5 & 48 & 0.65 & 26.5 & 48 & 0.78 & 33.9 & 48 & 0.78 & 34.8 & 48 & 0.78 & 34.9 & 48 \\
\hline 1981 & 0.52 & 19.8 & 48 & 0.73 & 44.0 & 72 & 0.53 & 20.1 & 48 & 0.52 & 19.9 & 48 & 0.65 & 26.7 & 48 \\
\hline 2004 & 0.43 & 36.5 & 96 & 0.40 & 45.0 & 132 & 0.80 & 30.0 & 96 & 0.50 & 30.1 & 60 & 0.40 & 30.4 & 60 \\
\hline 2006 & 0.80 & 78.4 & 120 & 0.40 & 120.2 & 120 & 0.77 & 53.5 & 60 & 0.78 & 51.6 & 60 & 0.59 & 52.0 & 60 \\
\hline
\end{tabular}

Explanations: PEPF, PEV, PWRMSE, SAR, SSR as under Table 2, $C_{p}=$ empirical coefficient, $T_{\text {lag }}-$ lag time, $T_{p}=$ time to peak. Source: own study.

The next stage of the calibration of model parameters is the general assessment of the quality, which was performed using the coefficient of efficiency $E$. The results are presented in Table 4.

Table 4. Values of the coefficient of efficiency $E(\%)$ for each objective function

\begin{tabular}{|c|c|c|c|c|c|}
\hline \multirow{2}{*}{ Wave } & \multicolumn{5}{|c|}{ Snyder's unit hydrograph } \\
\cline { 2 - 6 } & $P E P F$ & $P E V$ & $P W R M S E$ & SAR & SSR \\
\hline 1980 & 22.3 & 75.7 & 84.0 & 86.7 & 85.8 \\
\hline 1981 & -3.1 & 22.4 & 23.6 & 11.8 & 36.2 \\
\hline 2004 & 31.4 & 33.1 & 80.7 & -30.2 & 13.6 \\
\hline 2006 & -46.5 & -5.1 & 74.5 & 81.4 & 75.1 \\
\hline
\end{tabular}

Source: own study.

The lowest efficiency of both models was obtained when their parameters were optimized using $P E V$ and $P E P F$ functions. The reason for this, as previously mentioned, was that the model parameters were selected so that the consistency between the observed and calculated wave occurred only between $Q_{\max }$ and $V$ without considering the shape of hydrographs. Generally, when comparing both objective functions, slightly better results were obtained by optimizing the model parameters using $P E V$. Approximated values of the coefficient of efficiency $E$ were obtained when optimization of model parameters was performed using the other objective functions. This follows from the fact that the error values are calculated for the entire course of the hydrograph and not for its selected parts. When adopting the correctness criteria for the description of reality by the model given in the paper by MORIASI et al. [2007], who stated that the calibration process may be considered successfully completed when the value of Nash-Sutcliffe coefficient of efficiency is above $65 \%$, it can be concluded, that in the case of Snyder's model and parameter calibration using $P W R M S E$, this model can be considered correct in 3 out of 4 analyzed waves. The lowest value of the coefficient $E$ was obtained for the wave of 1981 and this resulted from the fact that the model imprecisely approximated the second culmination in this episode. In the case of SAR and SSR Snyder's model correctly described the two waves - from 1981 and 2006.

The final element of the model parameter calibration was the flexibility analysis. In the case of Snyder's model the impact of time lag $T_{\text {lag }}$ and flow coefficient $C_{p}$ on the flow values in culmination was analyzed. The calculations were performed for varying values of $T_{\text {lag }}$ in $5 \mathrm{~min}$ interval and $C_{p}$ of 0.1 intervals. The calculations revealed that in the case of $T_{\text {lag }}$ the model is inflexible. The calculated flexibility ratio for $T_{\text {lag }}$ equaled -0.33 . The change of $T_{\text {lag }}$ primarily postpones the hydrograph, while reducing the $Q_{\max }$ is observed mostly for low time lag values. For higher $T_{\text {lag }}$ 
values (over $30 \mathrm{~h}$ ) the results stabilize - Figure 4a. Time lag values are strongly correlated with the watershed slope, its shape and retention properties [BELETE 2009; SALAMI et al. 2009]. The model is flexible for the changes of $C_{p}$ parameter (the coefficient of efficiency value was 0.99 ). Increase of the $C_{p}$ parameter indicates the reduction of watershed retention capacity, which contributes to significant increase in the size of flows - Fig. 4b. With an increase of $C_{p}$ value by 0.6 , the flow $Q_{\max }$ was over 4 -times higher. The hydrograph postponing was not observed.
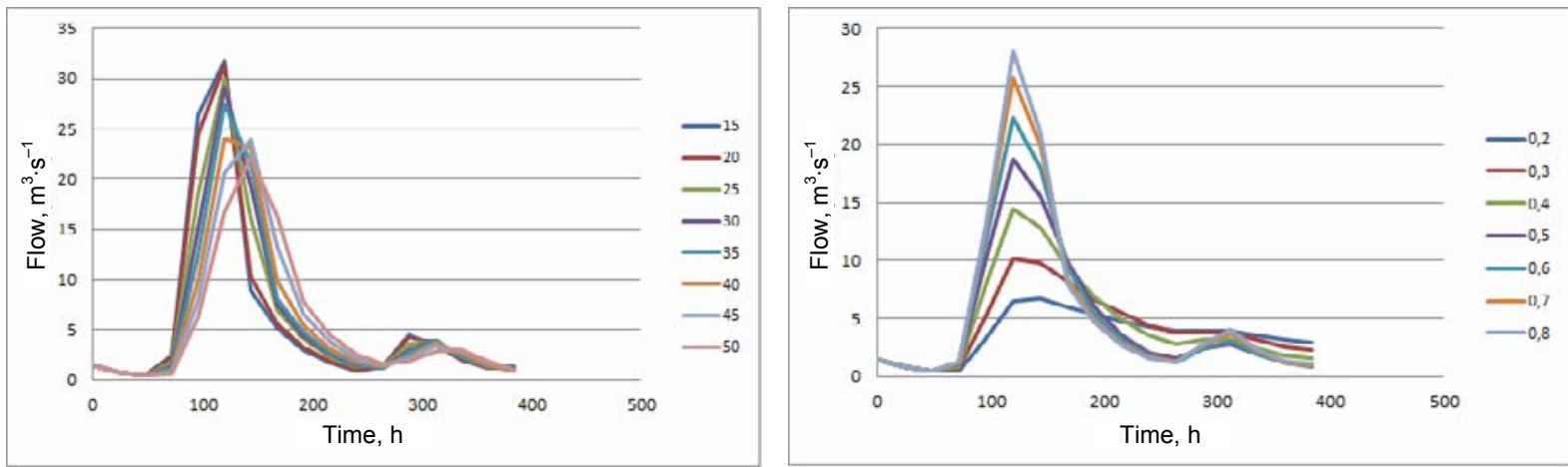

Fig. 4. Effect of a change of: a) lag time $\left(T_{\text {lag }}\right)$ and b) empirical coefficient $\left(C_{p}\right)$ parameter, on the shape of discharge hydrograph in Snyder's model; source: own study

\section{CONCLUSIONS}

1. The smallest differences between the maximum flow in the culmination of observed and calculated waves were obtained using PWRMSE. This follows from the fact that in the optimization procedure higher weights were assigned to the errors of flows located closer to the culmination flows.

2. Parameters of Snyder's model have large variability for different objective function.

3. Snyder's model is flexible to the change of $C_{p}$ coefficient. Increase of this parameter's value reduces the retention ability of a watershed and significantly affects the increasing flows without changing the shape of the hydrograph.

\section{REFERENCES}

Bahremand A., De Smedt F. 2008. Distributed hydrological modeling and sensitivity analysis in Torysa Watershed, Slovakia. Water Resources Management. Vol. 22. Iss. 3 p. $393-408$.

BELETE M.A. 2009. Synthetic unit hydrographs in the Upper Awash and Tekeze Basins. Methods, procedures and models. Saarbrücken. VDM Verlag Dr Müller. ISBN 978-3639169263 pp. 124.

CIEPIELOWSKI A. 1987. Badanie związków pomiędzy podstawowymi parametrami fal wezbraniowych w wybranych profilach rzek [Examination of the relationships between basic parameters of flood waves in selected river profiles]. Rozprawy Naukowe i Monografie. T. 63. Warszawa. Wydaw. SGGW. ISBN 83-00020-62-4 pp. 112.

CunDERLIK J.M., SimONOVIC S.P. 2004. Calibration, verification and sensitivity analysis of the HEC-HMS hydrologic model. Report IV. CFCAS project: Assessment of water resources risk and vulnerability to changing climatic conditions. University of Western pp. 113.

GĄDEK W. 2014. Fale hipotetyczne dla zlewni niekontrolowanych. W: Hydrologia w inżynierii i gospodarce wodnej [Theoretical flood waves for the non-gauged ca- tchments. In: Hydrology in engineering and water management]. T. 1. Monografie Komitetu Gospodarki Wodnej PAN. Komitet Gospodarki Wodnej PAN p. 139-149.

JHA M.K. 2011. Evaluating hydrologic response of an agricultural watershed for watershed analysis. Water. Vol. 3. Iss. 2 p. 604-617.

Karabová B., Sikorska A.E., Banasik K., Kohnová S. 2012. Parameters determination of a conceptual rainfallrunoff model for a small catchment in Carpathians. Annals of Warsaw University of Life Sciences - SGGW. Land Reclamation. No 44 (2) p. 155-162.

Khaleghi M.R., Ghodusi J., Ahmadi H. 2014. Regional analysis using the Geomorphologic Instantaneous Unit Hydrograph (GIUH) method. Soil and Water Resources. Vol. 9 p. 25-30.

Lenhart T., Eckhardt K., Fohrer N., Frede H.-G. 2002. Comparison of two different approaches of sensitivity analysis. Physics and Chemistry of the Earth. Parts A/B/C. Vol. 27. Iss. 9 p. 645-654.

MAIDMEND D.R., Hoogerwerf T.N. 2002. Parameter sensitivity in hydrologic modeling. Technical Report. Austin. University of Texas pp. 152.

Moriasi D.N., ARnOld J.G., VAN LiEW M.W., BingNer R.L., HARMel R.D., Veith T.L. 2007. Model evaluation guidelines for systematic quantification of accuracy in watershed simulations. American Society of Agricultural and Biological Engineers 50 (3) p. 885-900.

NASH J.E., SuTClifFe J.V. 1970. River flow forecasting through conceptual models part I: A discussion of principles. Journal of Hydrology. Vol. 10. Iss. 3 p. 282-290.

PONCE V.M. 1989. Engineering hydrology: Principles and practices. Upper Saddle River, New Jersey. Prentice Hall. ISBN 9780133154665 pp. 573.

Salami A.W., Bilewu S.O., Ayanshila A.M., Oritola S.F. 2009. Evaluation of synthetic unit hydrograph methods for the development of design storm hydrographs for rivers in South-West, Nigeria. Journal of American Science. Vol. 5. Iss. 4 p. 23-32.

SOCZYŃSKA U. 1997. Hydrologia dynamiczna [Dynamic hydrology]. Warszawa. Wydaw. Nauk. PWN. ISBN 8301-12310-9 pp. 409. 
VAŠšovÁ D. 2013. Comparison of rainfall-runoff models for design discharge assessment in a small ungauged catchment. Soil and Water Research. Vol. 8 p. 26-33.

WALĘGA A. 2013. Application of HEC-HMS programme for the reconstruction of a flood event in an uncontrolled basin. Journal of Water and Land Development. No. 18 p. $13-20$.

WAŁĘGA A. 2014. The importance of the objective functions and flexibility on calibration of parameters of
Clark instantaneous unit hydrograph. Geomatics, Landmanagement and Landscape. No. 2 p. 75-85.

Walęga A., GrZebinoga M., Paluszkiewicz B. 2011. On using the Snyder and Clark unit hydrograph for calculations of flood waves in a highland catchment (the Grabinka River example). Acta Scientiarum Polonorum. Formatio Circumiectus. Vol. 10. No. 2 p. 47-56.

\section{Andrzej WALĘGA}

\section{Znaczenie procesu kalibracji parametrów dla poprawności opisu wezbrań w modelu Snydera}

\section{STRESZCZENIE}

Słowa kluczowe: efektywność modelu, elastyczność modelu, hydrogram jednostkowy

W pracy porównano efektywność modelu Snydera w opisie wezbrań opadowych, którego parametry szacowano za pomocą różnych funkcji celu: procentowego błędu przepływu w kulminacji - PEPF, procentowego błędu objętości fali - PEV, ważonych średnich kwadratów błędu - PWRMSE, absolutnych sum reszt - SER i sum kwadratów reszt - SSR. Jakość modelu oceniono za pomocą współczynnika efektywności NashSutcliffe'a. Dodatkowo zbadano wpływ zmiany wartości parametrów na wielkości przepływu uzyskane z modelu za pomocą współczynnika elastyczności. Analizy prowadzono w zlewni rzeki Grabinki. Stwierdzono, że zastosowanie PWRMSE jako funkcji celu umożliwia na uzyskanie najlepszej zgodności wyników z modelu z przepływami obserwowanymi. Ponadto model Snydera jest wrażliwy na zmiany parametru $C_{p}$, który może być utożsamiany z retencyjnością zlewni. 